\title{
Article
}

\section{Is Allergy to Titanium Bone Fixation Plates a Problem?}

\author{
Iwona Niedzielska, Natalia Sitek-Ignac, Michał Bąk *(D) and Damian Niedzielski
}

Citation: Niedzielska, I.; Sitek-Ignac, N.; Bąk, M.; Niedzielski, D. Is Allergy to Titanium Bone Fixation Plates a Problem? Coatings 2022, 12, 214. https://doi.org/10.3390/ coatings 12020214

Academic Editor: Devis Bellucci

Received: 21 December 2021

Accepted: 2 February 2022

Published: 7 February 2022

Publisher's Note: MDPI stays neutral with regard to jurisdictional claims in published maps and institutional affiliations.

Copyright: (C) 2022 by the authors. Licensee MDPI, Basel, Switzerland. This article is an open access article distributed under the terms and conditions of the Creative Commons Attribution (CC BY) license (https:// creativecommons.org/licenses/by/ $4.0 /)$.

\author{
Department of Cranio-Maxillo-Facial Surgery, Medical University of Silesia in Katowice, ul. Francuska 20-24, \\ 40-027 Katowice, Poland; niedzielska.konsultant@wp.pl (I.N.); nsitekignac@gmail.com (N.S.-I.); \\ niedzielskidamian@gmail.com (D.N.) \\ * Correspondence: mbak@sum.edu.pl
}

\begin{abstract}
Open reduction and internal fixation (ORIF) with titanium fixation plates is the gold standard for maxillofacial fracture treatment. Titanium is considered a fully compatible material. However, reports of allergic reactions to titanium implants do occur. The aim of this work is to answer the question whether titanium devices used in the treatment of fractures in the craniofacial region can cause allergic reactions. The study comprised 50 subjects treated surgically for maxillofacial injuries with the use of titanium composite devices. Allergic tests were performed by the patch method. The control group consisted of 20 healthy people who did not have any titanium elements. There were no skin changes to titanium and its compounds in both the test and control groups. Only one patient had a positive skin test which showed an allergic reaction to silver nitrate. Titanium fixing elements, as well as titanium dental implants, according to our research, do not show allergic skin reactions.
\end{abstract}

Keywords: allergy; fracture; osteosynthesis; titanium; patch test; ORIF

\section{Introduction}

Allergic reaction usually occurs from minutes up to $72 \mathrm{~h}$ after repeated contact with an allergen [1-4]. Although allergic contact dermatitis (ACD) rarely constitutes a severe medical condition it may seriously decrease the quality of life [5]. Contact allergy may have a personal and socioeconomic influence on the affected individuals. It is also considered to have an impact on society [5]. Nickel exposure is considered to be the most common cause of contact allergy [6].

Manifestations of ACD include regional skin and mucosal lesions which may be accompanied by asthmatic conditions. Allergic contact stomatitis (ACS) may present as lichenoid lesions or hyperkeratosis, oral erythematous plaques, vesiculation, ulceration, edema, and may also include subjective symptoms of burning sensation, itchiness, or pain [4]. Rarely, lesions extend beyond the oral cavity, involving the facial skin and rest of the body, and resembling those of $\operatorname{ACD}[7,8]$. Many of the materials used in medicine, both metallic and non-metallic, are considered to be associated with elevated risk of allergy [4,9-11]. Chromium, nickel, palladium, copper, and acrylic compounds are known potential allergens $[8,10,12,13]$.

Metals in ionic form can bond with native proteins, forming haptenic antigens, or activating the degranulation of mastocytes and basophiles, leading to type I or type IV hypersensitive reaction development.

Titanium, used widely in dentistry, craniofacial surgery, and orthopedics, was considered fully biocompatible [14-16]. However, the frequency of reported allergic reactions to titanium is increasing [17-20]. Usually in medical applications Grade IV titanium is used, which is composed of titanium, iron, carbon, oxygen, and nitrogen. However, titanium alloys containing vanadium, nickel, aluminum, molybdenum, thallium, and niobium are also used. Titanium use in medicine is increasing; therefore, practitioners of different specialties encounter patients equipped with titanium implants in everyday practice $[8,21,22]$. Nowadays, open reduction and internal fixation (ORIF), with the aid of titanium hardware 
Figure $1 \mathrm{a}, \mathrm{b}$, is the gold standard for maxillofacial fracture treatment [23-25]. The influence of titanium allergy on the bone fracture healing process and surgical treatment outcomes remains unclear [26]. In orthopedics postoperative complications associated with titanium allergy are seldom reported [27-29]. Thomas et al. reported fever of unknown origin, impaired wound healing, skin lesions, and fracture treatment failures [27].

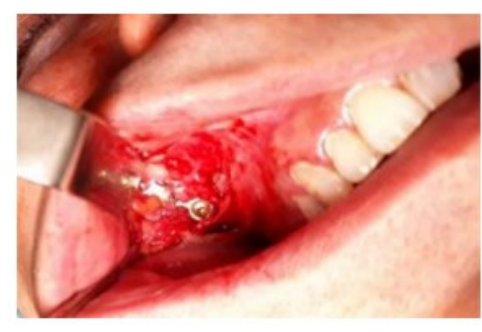

(a)

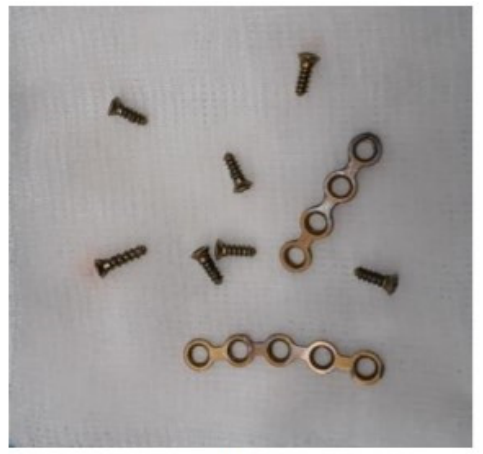

(b)

Figure 1. Bone plate fixation. (a) Hardware placed in oral cavity; (b) Hardware after retrieval.

In recent years, fixation with metal hardware has become the most common modality of treatment in post-traumatic bone fractures. The aim of open reduction and internal fixation is to restore the anatomical position of bone fragments and aid in the healing process.

Literature reports type I, III, and IV allergies in the orofacial region, with type IV being the most common in the oral cavity, in which characteristic features of allergy may appear after a few days, or even years, after contact with allergens [30].

The first reports on open reduction internal fixation methods with the use of plates and screws date back to the end of 19th century; however, further advancements in surgical techniques, metallurgy, and hardware design and fabrication were vital for the popularization of this method. It has since become the gold standard for fracture treatment [31,32]. Contemporarily, metallic alloys are widely used in fractures and reconstructive treatment, serving as both temporary and permanent devices.

Metal components used in the facial region may be permanently exposed to the adverse, acidic environment of the oral cavity. This acidity is caused by diet and bacteria, and results in chemical corrosion of metallic components. This results in the release of metal ions, which may circulate in the body or accumulate in local tissue, causing hypersensitivity reactions or tissue damage $[10,33]$. The hardware used in maxillofacial surgery is primarily composed of stainless steel, nickel-chrome or cobalt-chromium alloys, pure titanium, and titanium alloys [34,35]. The prevalence of contact allergy to metals averages $19.5 \%$ in the general population [36].

As a result of advancements in casting and metallurgy, and chemical industry development, titanium is increasingly used in paints, dyes, photocatalysts, and other ordinary items [37]. This, combined with the more frequent use of titanium in medicine, can increase the incidence of titanium allergic reactions [8].

The aim of this study was to determine if there is any relationship between metal hypersensitivity and titanium hardware ORIF surgical treatment outcomes in the maxillofacial region.

\section{Materials and Methods}

The study was carried out among patients admitted to the Medical University of Silesia Cranio-Maxillo-Facial-Surgery Department between 2017 and 2019. The inclusion and exclusion criteria are presented in Table 1. 
Table 1. Inclusion and exclusion criteria.

\begin{tabular}{|c|c|}
\hline \multicolumn{2}{|c|}{ Inclusion Criteria } \\
\hline \multicolumn{2}{|c|}{$\begin{array}{c}\text { Titanium Hardware Used for Maxillofacial Fracture Fixation } \\
\text { Titanium Dental Implants } \\
\text { Titanium Patient Specific Implants (PSIs) }\end{array}$} \\
\hline \multicolumn{2}{|c|}{ Exclusion Criteria } \\
\hline Permanent & Temporary \\
\hline $\begin{array}{c}\text { Lack of consent } \\
\text { Malignant disease } \\
\text { Autoimmune disease } \\
\text { Tattoo/skin lesion in interscapular area } \\
\text { General disease }\end{array}$ & $\begin{array}{l}\text { Active infectious disease } \\
\text { Antiallergic drugs } \\
\text { Steroid therapy } \\
\text { Extensive sunbathing } \\
\text { Cryotherapy } \\
\text { Vaccination }\end{array}$ \\
\hline
\end{tabular}

The inclusion criteria were:

- The presence of titanium implants used for maxillofacial fracture fixation; or

- The presence of titanium dental implants; or

- $\quad$ The presence of titanium patient specific implants (PSIs) reconstructing the maxillofacial bone;

and patients signed consent for inclusion in the research.

The exclusion criteria were divided into permanent and temporary. The former consisted of:

- Lack of patient's consent;

- Malignant disease;

- Autoimmune disease;

- Tattoo or skin lesion in interscapular or suprascapular area;

- General disease.

The temporary exclusion criteria included:

- Active infectious disease;

- Antiallergic drugs usage;

- $\quad$ Steroid therapy;

- Extensive sunbathing;

- Cryotherapy;

- Vaccination.

The study enrolled patients with maxillofacial fractures treated in the Craniomaxillofacial Surgery Department with the use of titanium hardware. The study was carried out after completion of fracture treatment, which is 2 to 6 months after surgery. Moreover, the control group was established, and the study was carried out in two groups:

1. Group 1 (research group) ( $\mathrm{n}=50$ ) —including the patients treated for maxillofacial fractures with the aid of titanium hardware.

2. Group 2 (control group) $(\mathrm{n}=20)$-comprising healthy subjects with no history of medical titanium usage.

The patients were subjected to:

1. Thorough medical history evaluation regarding prior orthopedic or dental procedures, in which titanium devices were used, and their occupational and environmental exposure to titanium or its compounds;

2. Clinical examination with emphasis on skin and oral mucosa screening for lesions of ACD or ACS type;

3. Skin allergy test with the aid of patch test.

The skin allergy test was performed using the patch method without breaking the continuity of tissues. The patch skin test was manufactured by Chemotechnique Diagnostics 
(Vellinge, Switzerland) in the form of patches containing allergens (titanium nitride 5\%, titanium oxide $10 \%$, zinc chloride $1 \%$, titanium oxalate $5 \%$, calcium titanate $10 \%$, and titanium $10 \%$ ) were placed on the back skin by sticking the IQ chamber in the interscapular or suprascapular area for a $48 \mathrm{~h}$ period. Results were collected at 2, 4, and 5 days. In doubtful situations, an additional reading was carried out after 7 days. The readings were graded according to the scoring system introduced by the International Contact Dermatitis Research Group (ICDRG) (Table 2) [38,39]. The research was approved by Medical University of Silesia Local Ethics Board (protocol code KNW/0022/KB1/78/17, date of approval 11 July 2017).

Table 2. The International Contact Dermatitis Research Group (ICDRG) clinical patch test reactions scoring system.

\begin{tabular}{ccc}
\hline Symbol & Relevance & Clinical Appearance \\
\hline$?+$ & Doubtful reaction & Faint, nonpalpable erythema \\
+ & Weak reaction & Erythema, infiltration, possible papules \\
++ & Strong reaction & Erythema, infiltration, papules, vesicles \\
+++ & Extreme reaction & Erythema, infiltration, coalescing vesicles; bullae or ulceration \\
- & Negative reaction & No changes \\
IR & Irritant reaction & No induration \\
NT & Not tested & \\
\hline
\end{tabular}

\section{Results}

The research group consisted of 50 patients, including 38 males and 12 females. The mean age was 31 years old. Timewise, in 2 cases testing was performed less than 6 months after the titanium implant placement; in 32 cases it was performed between 6 and 12 months after titanium implant placement; in 16 cases the test was performed more than 12 months after the titanium implant placement. Regarding the postoperative complications after titanium miniplate internal fixation, the most frequent was the trigeminal nerve paresthesia (23 cases) and edema (19 cases). In four cases wound dehiscence and hardware exposure were noted. The clinical symptoms are presented in Table 3.

Table 3. Clinical symptoms.

\begin{tabular}{|c|c|c|}
\hline Clinical Symptom & Number of Patients & Percentage (\%) \\
\hline \multicolumn{3}{|c|}{ Surgical complications } \\
\hline Paresthesia & 23 & 46 \\
\hline Wound dehiscence & 4 & 2 \\
\hline Loss of hardware & 0 & 0 \\
\hline Swelling & 19 & 38 \\
\hline \multicolumn{3}{|c|}{ Allergic manifestations } \\
\hline Eczema on skin & 3 & 6 \\
\hline Mucosal lesions & 2 & 2 \\
\hline
\end{tabular}

The allergic reaction is triggered when repeated exposure to the allergen happens. The aim of the research team was to establish any previous contact with titanium-containing agents. In eight cases there was evident prior contact with an allergen, but in 42 cases patients could not deny possible former contact. None of the patients were allergic to titanium or its compounds. Only one patient had a positive patch test for silver nitrate, which was a strong $(++)$ reaction (Figure 2 ).

Due to unequivocal research results, statistical analysis was not carried out. 


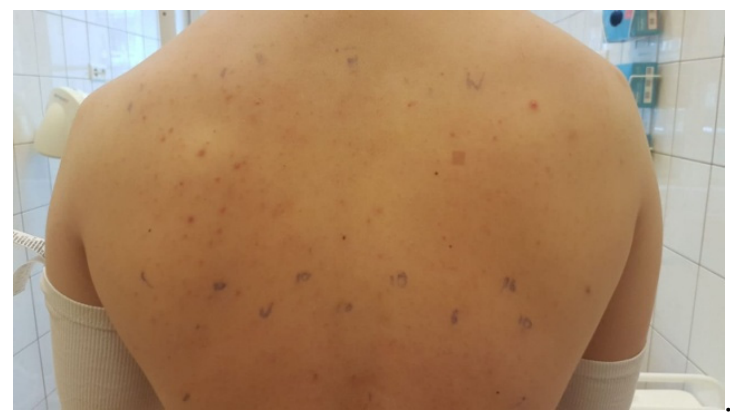

Figure 2. Patch test showing positive reaction to silver nitrate.

\section{Discussion}

The literature reports a plethora of clinical manifestations of metal hypersensitivity. Watchmaker and coauthors presented a case report of diffuse, pruritic, pink scaly patches on the trunk and extremities, which developed 3 weeks after placing of a stainless-steel locking fibular plate (DePuy Synthes West Chester, PA, USA) containing $2 \%$ manganese used for a lateral malleolus fracture fixation [40].

Allergy due to nickel sensitivity has been repeatedly reported by various authors. Stoddart described a case of anaphylaxis due to a nickel-plated cannula used for transfusion. McKenzie, Aitken, and Ridsdill-Smith reported urticaria related to Vitallium nail insertion and demonstrated that the reaction was caused by nickel, one of the Vitallium alloy components [41-43].

Contact hypersensitivity reactions to stainless steel and cobalt alloys have been described and were associated with chromium, cobalt, nickel, and rarely with molybdenum. On the other hand, titanium is believed not to provoke allergic reactions. Therefore, currently the most used material is titanium and its alloys. Even titanium described as commercially pure titanium supplied for implant manufacturing may be contaminated with nickel during the production process. Schuh et al. inspected the nickel content of commercially available titanium alloys $\left(\mathrm{TiAl}_{6} \mathrm{Nb}_{7}, \mathrm{TiAl}_{6} \mathrm{~V}_{4}\right)$ and pure titanium, and reported nickel concentrations of up to $0.034 \mathrm{wt} \%$. Iodide-titanium was reported to have the lowest concentration of nickel $(0.002 \mathrm{wt} \%)$ [44]. Therefore, corrosion of titanium hardware may release nickel and other trace elements into the tissues.

Although titanium has not been traditionally considered an allergen, cases of allergy to titanium have been reported $[45,46]$. Investigators of titanium contact allergy found that its incidence rate is about $0.6 \%$ [47].

Any occurrence of allergic reaction to biomaterial disqualifies it from clinical use. Although immediate hypersensitivity (Type I) or anaphylactic reactions to biomaterials are extraordinary, chromium and nickel salts-initiated Type I reactions, however these were not directly from implanted biomaterials [48]. The typical presentation of metal allergy in patients after open reduction internal fixation is delayed-type hypersensitivity eczema, which manifests as flare ups at previous patch test sites, exfoliative erythroderma, symmetrical intertriginous and flexural exanthema, and widespread dermatitis [49].

Patients with nickel contact dermatitis were reported to had higher IL-22 blood levels [11].

Patch testing is the preferred diagnostic method for delayed-type hypersensitivity, type IV reactions, and metal hypersensitivity [50,51]. Patient medical history, clinical findings, and the results of patch testing serve typically as diagnostic tools for titanium allergy. However, because of low epidermal penetration, some authors suppose that patch testing is unreliable $[52,53]$. Therefore, a number of alternative methods for the detection of contact allergy have been proposed-which include lymphocyte stimulation tests. However, there is no agreement on their suitability and reliability, so titanium allergy is diagnosed on the basis of clinical evaluation and patch testing [54]. Reports of delayed-type hypersensitivity date back to 1984 and 1985 when Peters et al. and Verbov, respectively, presented cases of allergic reactions after implantation of a titanium-encased 
pacemaker $[55,56]$. However, the allergology work-ups and patch test preparations are thought to have been insufficient in these studies. Thomas et al. described a case of ORIF treatment with the use of titanium hardware which resulted in impaired fracture healing and localized perioperative eczema. Although no reactions to titanium, nickel, chromium, or cobalt were revealed by patch testing, the lymphocyte transformation test revealed in vitro enhanced proliferation in response to titanium. Moreover, the removal of the titanium hardware resulted in fracture healing and the regression of eczema. Moreover, in vitro hyperreactivity to titanium was no longer observed [27].

In our study, all but one of the patch tests was negative, which may be associated with their low epidermal penetration. On the other hand, the clinical signs of allergy were also infrequent in our patients. This may lead to the hypothesis that observed surgical complications have to be attributed to other, non-allergic, factors. Both the concerns about reliability of the patch tests, and the relatively small sample size, constitute the limitations of this study.

Gingival hyperplasia around dental implants and chronic inflammation in the tissues surrounding titanium hardware were reported by Mitchell, but without proper allergology work up [57,58]. One case of ACD after placement of a dental implant in the maxilla was reported by Pigatto et al. Two cases of ACD after usage of titanium hardware in foot and metacarpal bone fractures were reported by Darlenski et al. [51,59]. Moreover, Oki Suwarsa described the case of systemic erythema with itching 7 days after ORIF treatment of a mandibular fracture with the aid of titanium hardware [60].

Certainly, the association between corrosion of titanium hardware, release of titanium particles, and the failure of implants is present; but the data are scarce, and no definitive statements can be made. The aforementioned reports of contact dermatitis or granulomatous reactions to titanium prove that further research is essential for clinical success.

\section{Conclusions}

According to the findings of our research, the complications of ORIF are unlikely to be associated with titanium allergy.

Author Contributions: Conceptualization, I.N.; funding acquisition, I.N.; investigation, N.S.-I. and D.N.; methodology, I.N., N.S.-I. and M.B.; supervision, I.N.; writing-original draft, N.S.-I. and M.B.; writing-review and editing, I.N. All authors have read and agreed to the published version of the manuscript.

Funding: This project was funded by the Ministry of Science and Higher Educations, Poland (KNW$1-192 / \mathrm{N} / 7 / \mathrm{K})$.

Institutional Review Board Statement: The study was conducted according to the guidelines of the Declaration of Helsinki, and approved by the Ethics Committee of Bioethical Commission, Medical University of Silesia in Katowice (protocol code KNW/0022/KB1/78/17, date of approval 11 July 2017).

Informed Consent Statement: Informed consent was obtained from all subjects involved in the study.

Data Availability Statement: Not applicable.

Conflicts of Interest: The authors declare no conflict of interest.

\section{References}

1. Galli, S.J.; Tsai, M.; Piliponsky, A.M. The development of allergic inflammation. Nature 2008, 454, 445-454. [CrossRef] [PubMed]

2. Kemp, S.F. The post-anaphylaxis dilemma: How long is long enough to observe a patient after resolution of symptoms? Curr. Allergy Asthma Rep. 2008, 8, 45-48. [CrossRef] [PubMed]

3. Kay, A.B. Allergy and Allergic Diseases. N. Engl. J. Med. 2001, 344, 30-37. [CrossRef] [PubMed]

4. Feller, L.; Wood, N.H.; Khammissa, R.A.G.; Lemmer, J. Review: Allergic contact stomatitis. Oral Surgery Oral Med. Oral Pathol. Oral Radiol. 2017, 123, 559-565. [CrossRef] [PubMed]

5. Kalboussi, H.; Kacem, I.; Aroui, H.; El Maalel, O.; Maoua, M.; Brahem, A.; El Guedri, S.; Chatti, S.; Ghariani, N.; Mrizak, N Impact of Allergic Contact Dermatitis on the Quality of Life and Work Productivity. Dermatol. Res. Pr. 2019, 2019, 1-8. [CrossRef]

6. Wojciechowska, M.; Czajkowski, R.; Kowaliszyn, B.; Żbikowska-Gotz, M.; Bartuzi, Z. Analysis of skin patch test results and metalloproteinase-2 levels in a patient with contact dermatitis. Adv. Dermatol. Allergol. 2015, 32, 154-161. [CrossRef] 
7. Garau, V.; Masala, M.G.; Cortis, M.C.; Pittau, R. Contact stomatitis due to palladium in dental alloys: A clinical report. J. Prosthet. Dent. 2005, 93, 318-320. [CrossRef]

8. Hosoki, M.; Nishigawa, K.; Miyamoto, Y.; Ohe, G.; Matsuka, Y. Allergic contact dermatitis caused by titanium screws and dental implants. J. Prosthodont. Res. 2016, 60, 213-219. [CrossRef]

9. DE Rossi, S.S.; Greenberg, M.S. Intraoral Contact Allergy: A Literature Review and Case Reports. J. Am. Dent. Assoc. 1998, 129, 1435-1441. [CrossRef]

10. Ditrichova, D.; Kapralova, S.; Tichy, M.; Ticha, V.; Dobesova, J.; Justova, E.; Eber, M.; Pirek, P. Oral lichenoid lesions and allergy to dental materials. Biomed. Pap. 2007, 151, 333-339. [CrossRef]

11. Ricciardi, L.; Minciullo, P.L.; Saitta, S.; Trombetta, D.; Saija, A.; Gangemi, S. Increased serum levels of IL-22 in patients with nickel contact dermatitis. Contact Dermat. 2009, 60, 57-58. [CrossRef] [PubMed]

12. Minciullo, P.L.; Paolino, G.; Vacca, M.; Gangemi, S.; Nettis, E. Unmet diagnostic needs in contact oral mucosal allergies. Clin. Mol. Allergy 2016, 14, 1-8. [CrossRef] [PubMed]

13. Rai, R.; Dinakar, D.; Kurian, S.S.; Bindoo, Y. Investigation of contact allergy to dental materials by patch testing. Indian Dermatol. Online J. 2014, 5, 282-286. [CrossRef] [PubMed]

14. Sarraf, M.; Ghomi, E.R.; Alipour, S.; Ramakrishna, S.; Sukiman, N.L. A state-of-the-art review of the fabrication and characteristics of titanium and its alloys for biomedical applications. Bio-Design Manuf. 2021, 1, 1-25. [CrossRef] [PubMed]

15. Pacifici, L. Metals used in maxillofacial surgery. Oral Implant. 2016, 9, 107-111. [CrossRef] [PubMed]

16. Quinn, J.; McFadden, R.; Chan, C.-W.; Carson, L. Titanium for Orthopedic Applications: An Overview of Surface Modification to Improve Biocompatibility and Prevent Bacterial Biofilm Formation. iScience 2020, 23, 101745. [CrossRef]

17. Poli, P.P.; de Miranda, F.V.; Polo, T.O.B.; Júnior, J.F.S.; Neto, T.J.L.; Rios, B.R.; Assunção, W.G.; Ervolino, E.; Maiorana, C.; Faverani, L.P Titanium Allergy Caused by Dental Implants: A Systematic Literature Review and Case Report. Mater. 2021, 14, 5239. [CrossRef]

18. Tanwar, N.; Prakash, C.; Chaudhary, K.; Tewari, S.; Bhagavatheeswaran, S. Titanium allergy in dentistry: A new allergen in rapidly evolving implant dentistry. Contemp. Clin. Dent. 2021, 12, 317. [CrossRef]

19. Singh, R.; Lehl, G.; Hussain, A.B.; Abhang, T.N.; Kulkarni, M.M.; Elagib, M.F.A.; Tiwari, R.V.C. Prevalence of Titanium Hypersensitivity in Patients with Titanium Implants: A Systematic Review and Meta-Analysis. J. Pharm. Bioallied Sci. 2021, 13, S1345. [CrossRef]

20. Comino-Garayoa, R.; Brinkmann, J.C.-B.; Peláez, J.; López-Suárez, C.; Martínez-González, J.M.; Suárez, M.J. Allergies to Titanium Dental Implants: What Do We Really Know about Them? A Scoping Review. Biology 2020, 9, 404. [CrossRef]

21. de Viteri, V.S.; Fuentes, E. Titanium and Titanium Alloys as Biomaterials. In Tribology: Fundamentals and Advancements; Bod-Books on Demand: Norderstedt, Germany, 2013; pp. 155-181. [CrossRef]

22. Rack, H.; Qazi, J. Titanium alloys for biomedical applications. Mater. Sci. Eng. C 2006, 26, 1269-1277. [CrossRef]

23. Capucha, T.; Shilo, D.; Aslan, R.A.; Blanc, O.; Ginini, J.G.; Semel, G.; Emodi, O.; Rachmiel, A. Is Open Reduction Internal Fixation Using Titanium Plates in the Mandible as Successful as We Think? J. Craniofacial Surg. 2021. Publish ahead. [CrossRef] [PubMed]

24. Ravikumar, C.; Bhoj, M. Evaluation of postoperative complications of open reduction and internal fixation in the management of mandibular fractures: A retrospective study. Indian J. Dent. Res. 2019, 30, 94-96. [PubMed]

25. Chrcanovic, B.R. Open versus closed reduction: Comminuted mandibular fractures. Oral Maxillofac. Surg. 2012, 17, 95-104. [CrossRef]

26. Richards, L.J.; Streifel, A.; Rodrigues, J.M. Utility of Patch Testing and Lymphocyte Transformation Testing in the Evaluation of Metal Allergy in Patients with Orthopedic Implants. Cureus 2019, 11, e5761. [CrossRef]

27. Thomas, P.; Bandl, W.-D.; Maier, S.; Summer, B.; Przybilla, B. Hypersensitivity to titanium osteosynthesis with impaired fracture healing, eczema, and T-cell hyperresponsiveness in vitro: Case report and review of the literature. Contact Dermat. 2006, 55, 199-202. [CrossRef]

28. Lalor, P.; Revell, P.; Gray, A.; Wright, S.; Railton, G.; Freeman, M. Sensitivity to titanium. A cause of implant failure? J. Bone Jt. Surgery. Br. Vol. 1991, 73-B, 25-28. [CrossRef]

29. Müller, K.; Valentine-Thon, E. Hypersensitivity to titanium: Clinical and laboratory evidence. Neuro Endocrinol. Lett. 2006, 27 (Suppl. 1), 31-35.

30. Chaturvedi, T. Allergy related to dental implant and its clinical significance. Clin. Cosmet. Investig. Dent. 2013, 5, 57-61. [CrossRef]

31. Lane, W. On the Advantage of the Steel Screw in the Treatment of Ununited Fractures. Lancet 1893, 142, 1500-1501. [CrossRef]

32. Yaremchuk, M.J.; Gruss, J.S.; Manson, P.N.; Vasconez, H.C. Rigid Fixation of the Craniomaxillofacial Skeleton. Plast. Reconstr. Surg. 1993, 92, 168. [CrossRef]

33. Simonsen, A.; Johansen, J.; Deleuran, M.; Mortz, C.; Skov, L.; Sommerlund, M. Children with atopic dermatitis may have unacknowledged contact allergies contributing to their skin symptoms. J. Eur. Acad. Dermatol. Venereol. 2018, 32, 428-436. [CrossRef]

34. Yoshihisa, Y.; Shimizu, T. Metal Allergy and Systemic Contact Dermatitis: An Overview. Dermatol. Res. Pract. 2012, $2012,749561$. [CrossRef]

35. Roach, M. Base Metal Alloys Used for Dental Restorations and Implants. Dent. Clin. N. Am. 2007, 51, 603-627. [CrossRef]

36. Thyssen, J.P.; Linneberg, A.; Menné, T.; Johansen, J.D. The epidemiology of contact allergy in the general population-Prevalence and main findings. Contact Dermat. 2007, 57, 287-299. [CrossRef] 
37. Kim, K.T.; Eo, M.Y.; Nguyen, T.T.H.; Kim, S.M. General review of titanium toxicity. Int. J. Implant. Dent. 2019, 5, 10. [CrossRef] [PubMed]

38. Goel, S.; Shetty, V.H.; Eram, H.; Babu, A.M. Study of the clinical pattern of contact dermatitis over the face and its correlation with patch testing. Int. J. Res. Dermatol. 2019, 5, 350-356. [CrossRef]

39. Spiewak, R.; Pietowska, J.; Curzytek, K. Nickel: A unique allergen-from molecular structure to European legislation. Expert Rev. Clin. Immunol. 2007, 3, 851-859. [CrossRef] [PubMed]

40. Watchmaker, J.; Collins, R.; Chaney, K. Allergic Contact Dermatitis to Manganese in Metallic Implant. Dermat. 2015, 26, 149-150 [CrossRef]

41. Calnan, C.D. Nickel Dermatitis. Br. J. Dermatol. 1956, 68, 229-236. [CrossRef] [PubMed]

42. McKenzie, A.W.; Aitken, C.V.; Ridsdill-Smith, R. Urticaria after insertion of Smith-Petersen Vitallium nail. BMJ 1967, 4, 36. [CrossRef] [PubMed]

43. Stoddart, J. Nickel sensitivity as a cause of infusion reactions. Lancet 1960, 276, 741-742. [CrossRef]

44. Schuh, M.A.; Thomas, P.; Kachler, W.; Göske, J.; Wagner, L.; Holzwarth, U.; Forst, R. Das Allergiepotenzial von Implantatwerkstoffen auf Titanbasis. Der Orthopäde 2005, 34, 327-333. [CrossRef] [PubMed]

45. Hosoki, M.; Nishigaw, K. Dental Metal Allergy. Contact Dermatitis 2011, 1, 89-108. [CrossRef]

46. Goutam, M.; Giriyapura, C.; Mishra, S.K.; Gupta, S. Titanium allergy: A literature review. Indian J. Dermatol. 2014, 59, 630. [CrossRef]

47. Sicilia, A.; Cuesta, S.; Coma, G.; Arregui, I.; Guisasola, C.; Ruiz, E.; Maestro, A. Titanium allergy in dental implant patients: A clinical study on 1500 consecutive patients. Clin. Oral Implant. Res. 2008, 19, 823-835. [CrossRef]

48. Haug, R.H. Retention of asymptomatic bone plates used for orthognathic surgery and facial fractures. J. Oral Maxillofac. Surg. 1996, 54, 611-617. [CrossRef]

49. Abbas, A.K.; Lichtman, A.H.; Pillai, S.; Baker, D.L. Basic Immunology: Functions and Disorders of the Immune System, 6th ed.; Elsevier: Philadelphia, PA, USA, 2020.

50. Wahlberg, J.E.; Lindberg, M. Patch Testing. In Contact Dermatitis; Springer: Berlin/Heidelberg, Germany, 2006.

51. Pigatto, P.D.; Brambilla, L.; Ferrucci, S.; Zerboni, R.; Somalvico, F.; Guzzi, G. Systemic allergic contact dermatitis associated with allergy to intraoral metals. Dermatol. Online J. 2014, 20, 20. [CrossRef]

52. Hallab, N.; Merritt, K.; Jacobs, J.J. Metal Sensitivity in Patients with Orthopaedic Implants. J. Bone Jt. Surg. 2001, 83, 428-436. [CrossRef]

53. Hallab, N.; Mikecz, K.; Jacobs, J. A Triple Assay Technique for the Evaluation of Metal-induced, Delayed-type Hypersensitivity Responses in Patients with or Receiving Total Joint Arthroplasty. J. Biomed. Mater. Res. 2000, 53, 480-489. [CrossRef]

54. Fage, S.W.; Muris, J.; Jakobsen, S.S.; Thyssen, J.P. Titanium: A review on exposure, release, penetration, allergy, epidemiology, and clinical reactivity. Contact Dermat. 2016, 74, 323-345. [CrossRef] [PubMed]

55. Verbov, J. Pacemaker contact sensitivity. Contact Dermat. 1985, 12, 173. [CrossRef]

56. Peters, M.S.; Schroeter, A.L.; Van Hale, H.M.; Broadbent, J.C. Pacemaker contact sensitivity. Contact Dermat. 1984, 11, 214-218. [CrossRef] [PubMed]

57. Mitchell, D.L.; Synnott, S.A.; Van Dercreek, J.A. Tissue reaction involving an intraoral skin graft and CP titanium abutments: A clinical report. Int. J. Oral Maxillofac. Implant. 1990, 5, 79-84.

58. Holgers, K.-M.; Thomsen, P.; Tjellström, A. Persistent Irritation of the Soft Tissue Around an Osseointegrated Titanium Implant: Case Report. Scand. J. Plast. Reconstr. Surg. Hand Surg. 1994, 28, 225-230. [CrossRef] [PubMed]

59. Darlenski, R.B.; Demerdjieva, Z.; Kazandjieva, J.S.; Tsankov, N.K. Systemic Contact Dermatitis to Nickel. OA Dermatol. 2014, 2 , 7.

60. Suwarsa, O.; Rahardjo, R.M.; Sutedja, E.; Dharmadji, H.P.; Hindritiani, R.; Gunawan, H. Systemic contact dermatitis due to corrosion of titanium-coated nickel and cobalt bone plate fixation. Medicine 2017, 96, e9120. [CrossRef] 